\title{
ANALISIS ASPEK KEPERILAKUAN PADA PENERAPAN SISTEM AKUNTANSI PERSEDIAAN DI CV. SENYUM MEDIA
}

\author{
Berlinetta Setia Wandhana ${ }^{a}$, Muhammad Firdaus ${ }^{b}$, Nanda Widaninggar ${ }^{c}$ \\ ${ }^{a}$ Mahasiswa STIE MANDALA, berlinettasetiawanhana123@gmail.com \\ ${ }^{b}$ Dosen STIE MANDALA, muhammadfirdaus2011@gmail.com \\ ${ }^{c}$ Dosen STIE MANDALA, nanwiedha@stie-mandala.ac.id \\ E-mail Penulis Korespondensi: nanwiedha@stie-mandala.ac.id
}

I N F O A R T I K E L

Riwayat Artikel:

2 September 2021

30 September 2021

29 Oktober 2021

Keywords:

Attitude,Motivation, Emotion, Perception, Learning, Personality, and

InventoryAccounting System

\section{Kata Kunci:}

Sikap, Motivasi, Emosi, Persepsi,Pembelajaran, Kepribadian, dan Sistem Akuntansi Persediaan
A B S TR A C T

This study aims to analyze the Behavioral Aspects of $C V$. Senyum Media The object of this research is Senyum Media Jl. Kalimantan, Senyum Media Jl. Trunojoyo, Senyum Media Jl.Ambulu. The population in this study were employees who worked on CV. Senyum Media. This study uses a saturation sample. The analytical tools in this study used Instrument Tests (Validity Test and Reliability Test), Classical Assumption Test (Normality Test, Multicollinearity Test, Heteroskadestisity Test), and Multiple Linear Regression Analysis (Coefficient of Determination, Simultaneous Test Test ( $F$ test) and Partial Test ( $t$ test).The results showed that Attitude, Motivation, Emotion, Perception, Learning, and Personality had a positive effect on the Inventory Accounting System.This indicates that if Attitude, Motivation, Emotion, Perception, Learning, and Personality greatly support the performance of the Inventory Accounting System. to work optimally.

\section{A B S T R A K}

Penelitian ini bertujuan untuk menganalisis Aspek Keperilakuan pada CV. Senyum Media. Objek penelitian ini adalah Senyum Media Jl. Kalimantan, Senyum Media Jl. Trunojoyo, Senyum Media Jl.Ambulu. Populasi dalam penelitian ini adalah karyawan yang bekerja pada CV. Senyum Media. Penelitian ini menggunakan Sampel Jenuh. Alat analisis dalam penelitian ini menggunakan Uji Instrumen (Uji Validitas dan Uji Realibilitas), Uji Asumsi Klasik (Uji Normalitas, Uji Multikolinieritas, Uji Heteroskadestisitas), dan Analisis regresi linier berganda (Koefisien Determinasi, Uji Uji Simultan (uji F) dan Uji Parsial (uji t). Hasil penelitian menunjukkan bahwa Sikap, Motivasi, Emosi, Persepsi, Pembelajaran, dan Kepribadian berpengaruh positif pada Sistem Akuntansi Persediaan. 
Hal ini menunjukkan bahwa jika Sikap, Motivasi, Emosi, Persepsi, Pembelajaran, dan Kepribadian sangat menunjang kinerja Sistem Akuntansi Persediaan untuk bekerja secara optimal.

\section{PENDAHULUAN}

Sistem tidak terlepas dari Sumber Daya Manusia yang berperan penting untuk menjalankan sistem tersebut. Meskipun secara teknis sistem telah dinilai baik dan didukung oleh komputerisasi dan kecanggihan teknologi, akan tetapi penempatan sumber daya manusia kadang juga dapat menjadikan sumber kesalahan, sehingga terjadi kegagalan output yang tidak diharapkan. Dengan demikian, perlu adanya pertimbangan mengenai aspek keperilakuan dalam hal mendesain, menganalisa, mengimplementasikan dan menjalankan sebuah sistem.

Akuntansi keperilakuan (behavioral accounting) adalah bagian dari disiplin ilmu akuntansi yang mengkaji hubungan antara perilaku manusia dan sistem akuntansi, serta dimensi keperilakuan dari organisasi tempat manusia dan sistem akuntansi itu berada dan diakui keberadaannya. Dengan demikian maka definisi akuntansi keperilakuan adalah suatu studi tentang perilaku akuntan atau non-akuntan yang dipengaruhi oleh fungsifungsi akuntansi dan pelaporan (I Wayan Suartana, 2010).

Persediaan adalah termasuk elemen yang memiliki likuiditas tinggi dalam laporan keuangan atau neraca, oleh karena itu sangat dibutuhkan ketelitian yang ekstra dari segi pencatatan, perhitungan persediaan, penyimpanan persediaan serta berbagai perlakuan untuk mengelola persediaan yang ada agar terhindar dari kerugian yang disebabkan oleh kelalaian bahkan kecurangan. Dengan demikian maka sebuah sistem akuntansi persediaan harus dirancang secara efektif dan efisien serta diharapkan dapat berjalan sesuai dengan tujuan.

CV. Senyum Media merupakan perusahaan yang menawarkan berbagai macam produk-produk alat tulis dan perlengkapan kantor, perlengkapan rumah tangga, kosmetik, dan alat-alat kesehatan. Persediaan adalah komponen utama di dalam memenuhi kebutuhan pelanggan pada saat ini atau masa depan. Berdasarkan hal tersebut, maka sistem akuntansi persediaan yang diterapkan haruslah efektif dan efisien serta memiliki unsur pengendalian yang memadai agar menghindari terjadinya kecurangan dalam sistem tersebut.

Perilaku karyawan yang baik dapat menjadi faktor pendukung utama dalam keberhasilan sistem akuntansi persediaan, mengingat karyawan merupakan pihak yang menjalankan sistem yang diterapkan pada perusahaan. Pentingnya manajemen persediaan yang baik adalah untuk mengatur setiap persediaan yang ada di dalam perusahaan, dimulai dari cara memperoleh persediaan tersebut, cara penyimpanan, hingga bagaimana persediaan tersebut dimanfaatkan ataupun dikeluarkan. Tentunya manajemen persediaan merupakan bagian penting dari perusahaan. Apalagi jika perusahaan tersebut bergerak dalam bidang perdagangan. Manajemen persediaan juga membantu dalam mengatur persediaan perusahaan agar tidak terjadi kekurangan ataupun kelebihan stock barang agar tidak kadaluwarsa.

Perilaku karyawan yang sering melakukan kesalahan akan sangat memengaruhi dalam pembelian barang kepada supplier dengan sistem manual, pada saat melakukan otorisasi maupun saat pencatatan pembelian barang dagang yang terkadang terlalu banyak 
dibeli tetapi belum tentu dapat terjual semua, sehingga barang dagang yang akan dipasarkan menjadi tidak terorganisir dengan baik dan menumpuk di bagian persediaan barang dagang di gudang. Kesalahan lain yang sering terjadi dalam menggunakan sistem manual di antaranya informasi yang dihasilkan tidak akurat, resiko salah catat, dan ketidaktelitian.

Aspek keperilakuan memiliki beberapa indikator, diantaranya sikap, motivasi, emosi, persepsi, pembelajaran, dan kepribadian. Sikap adalah suatu hal yang mempelajari seluruh tendensi tindakan, baik yang menguntungkan maupun kurang menguntungkan. Motivasi adalah proses yang dimulai dengan definisi fisiologis atau psikologis yang menggerakkan perilaku atau dorongan yang ditujukan untuk tujuan insentif. Emosi adalah perasaan intensyang diarahkan pada seorang atau sesuatu. Persepsi adalah bagaimana orang-orang melihat atau menginterprestasikan peristiwa, objek, serta manusia. Pembelajaran adalah proses di mana perilaku baru yang diperlukan. Kepribadian mengacu pada bagian karakteristik psikologi dalam diri seseorang yang mencerminkan bagaimana orang tersebut merespons lingkungannya.

Penelitian ini juga dilatarbelakangi bahwa pada CV. Senyum Media menerapkan Sistem Informasi Akuntansi berbasis manual dan terkomputerisasi. Pada sistem akuntansi berbasis manual, masalah yang sering terjadi adalah saat melakukan pengendalian terhadap persediaan barang dagang, terkadang sistem berbasis manual tidak mengakomodasi secara tepat pada saat pembelian barang kepada supplier. Sistem berbasis manual dalam pembelian barang juga kurang update.

Tingkas Kurniyanti (2019) ; Evaliana Marantika Akay, Agus T. Poputra, Meily Y. B. Kalalo (2016) ; Rombe, Poputra dan Kalalo (2015) ; menyatakan bahwa Sikap, Motivasi, Persepsi dan Emosi secara parsial berpengaruh signifikan terhadap sistem akuntansi persediaan barang. Temen Koesmono (2004), menyatakan bahwa Kepribadian berpengaruh terhadap perilaku karyawan secara positif, Kepribadian juga berpengaruh terhadap komitmen organisasi secara positif. Ketut Sudarma, Eva M. Sakdiyah (2007), menyatakan bahwa Pembelajaran berpengaruh positif terhadap prestasi belajar akuntansi.Sedangkan Wulan Mogontha, Grace B Nangoi, Natalia Gerungai (2017), menyatakan bahwa Sikap, Motivasi, dan Emosi tidak berpengaruh terhadap sistem akuntansi yang ada di PT. Sinar Galesong Prima.

Urgensi dari dilakukannya penelitian ini adalah untuk mengevaluasi sejauh mana aspek keperilakuan berperan terhadap sistem akuntansi persediaan CV. Senyum Media, selain itu dapat diperoleh informasi tentang kualitas penerapan sistem akuntansi persediaan ditinjau dari aspek keperilakuan.

\section{METODE PENELITIAN}

\section{Objek Penelitian}

Adapun objek dalam penelitian ini adalah CV. Senyum Media, yang terdiri dari kantor pusat dan 2 kantor cabang. Kantor pusat CV. Senyum Media terletak di Jl. Kalimantan No.07, Krajan Timur-Sumbersari, Kecamatan Sumbersari, Kabupaten Jember, Jawa Timur ; Kantor cabang CV. Senyum Media terletak di Jl. Trunojoyo No.21, Kebondalem, Kecamatan Kepatihan ; dan kantor cabang CV. Senyum Media yang terletak di Jl. Ambulu, Kecamatan Balung Lor.

\section{Populasi}

Populasi menurut Arikunto (2006:130), adalah keseluruhan subjek penelitian. Jadi 
populasi adalah jumlah keseluruhan populasi yang merupakan hasil pengukuran atau perhitungan secara kualitatif maupun kuantitatif mengenai karakteristik tertentu dari semua anggota kumpulan yang lengkap dan jelas yang ingin dipelajari sifat-sifatnya. Dalam penelitian ini populasi yang diambil adalah karyawan CV. Senyum Media yang berjumlah 167 orang.

\section{Sampel}

Sampel menurut Sugiyono (2017) menyatakan bahwa sampel adalah bagian dari jumlah dan karakteristik yang dimiliki oleh populasi. Sampel dilakukan karena peneliti memiliki keterbatasan dalam melakukan penelitian baik dari segi waktu, tenaga, dana dan jumlah populasi yang sangat banyak. Maka peneliti harus mengambil sampel yang benarbenar representatif (dapat mewakili). Sampel dalam penelitian ini dipilih menggunakan metode sampel jenuh yang bertujuan untuk mendapatkan sampel sesuai kriteria yang ditentukan.

Kriteria penentuan yang digunakan untuk memilih sampel dalam penelitian ini adalah :

1. Staf atau pegawai yang melaksanakan fungsi Gudang dan Input

2. Staf atau pegawai yang melaksanakan fungsi Kasir

3. Staf atau pegawai yang melaksanakan fungsi Administrasi Keuangan

4. Staf atau pegawai yang melaksanakan fungsi Personalia

Berdasarkan kriteria tersebut, jumlah sampel yang diperoleh adalah 75 orang.

\section{Jenis Penelitian}

Jenis penelitian ini adalah penelitian asosiatif dengan metode deskriptif kuantitatif, yaitu menggambarkan data yang diperoleh dan menganalisis data yang ada secara kuantitatif (statistic). Penelitian deskriptif meliputi penilaian sikap atau pendapat terhadap individu, organisasi, keadaan, ataupun prosedur. Data deskriptif pada umumnya dikumpulkan melalui daftar pertanyaan survey, wawancara, ataupun observasi (Indrawan dan Yaniawati, 2014:56).

Penelitian kuantitatif menurut Margono (2000) adalah suatu proses menemukan pengetahuan yang menggunakan data berupa angka sebagai alat menemukan keterangan mengenai apa yang ingin kita ketahui. Menurut Supriyanto dan Machfudz (2010:287), Penelitian Eksplanatori adalah untuk menguji hipotesis antar variabel yang dihipotesiskan.

\section{Variabel Penelitian}

Variabel dalam penelitian ini, variabel terikat atau variabel dependen adalah Sistem Akuntansi Persediaan (Y), sedangkan variabel bebas atau independen yaitu Sikap (X1), Motivasi (X2), Emosi (X3), Perspesi (X4), Pembelajaran (X5), dan Kepribadian (X6).

\section{Uji Kualitas Data}

Uji kualitas data meliputi uji validitas dan reliabilitas digunakan untuk menguji data yang menggunakan pertanyaan atau kuesioner untuk melihat jawaban responden tersebut layak atau belum pertanyaan-pertanyaan digunakan untuk mengambil data (Sujarweni 2015:160).

\section{Teknik Analisis Data}

Teknik analisis data dalam penelitian ini menggunakan uji asumsi klasik dan 
analisis regresi linier berganda. Alat uji yang digunakan yaitu ui determinasi untuk mejelaskan seberapa jauh kemampuan variabel dependen $(\mathrm{X})$ terhadap variabel idependen (Y). Nilai koefisien determinasi antara nol dan satu (Ghozali,2016:95), uji t untuk mengukur mengetahui berapa besar pengaruh antar variabel secara parsial, sedangkan uji $\mathrm{F}$ untuk mengukur pengaruh antar variabel secara simultan alat uji yang digunakan adalah uji F.

\section{HASIL DAN PEMBAHASAN}

\section{Uji Kualitas Instrumen}

1. Uji Validitas

Dasar pengambilan keputusan untuk uji validitas dengan membandingkan hasil $\mathrm{r}$ hitung dengan $\mathrm{r}$ tabel dimana df-2 dengan sig 5\%. Berdasarkan hal tersebut diperoleh $r$ tabel sebesar 0.227 , maka jika $0.227<\mathrm{r}$ hitung maka poin-poin pernyataan kuesioner dinyatakan valid.

Tabel 3.1

Uji Validitas

\begin{tabular}{|c|c|c|c|c|}
\hline Variabel & Indikator & $\mathbf{r}$-hitung & $\mathbf{r}$ - tabel & Ket \\
\hline \multirow[t]{5}{*}{$\mathrm{X} 1$ = Sikap } & $\mathrm{X} 1.1$ & 0,762 & 0,227 & Valid \\
\hline & $\mathrm{X} 1.2$ & 0,501 & 0,227 & Valid \\
\hline & $\mathrm{X} 1.3$ & 0,771 & 0,227 & Valid \\
\hline & $\mathrm{X} 1.4$ & 0,643 & 0,227 & Valid \\
\hline & $\mathrm{X} 1.5$ & 0,746 & 0,227 & Valid \\
\hline \multirow[t]{3}{*}{$\mathrm{X} 2=$ Motivasi } & $\mathrm{X} 2.1$ & 0,806 & 0,227 & Valid \\
\hline & $\mathrm{X} 2.2$ & 0,600 & 0,227 & Valid \\
\hline & $\mathrm{X} 2.3$ & 0,856 & 0,227 & Valid \\
\hline \multirow[t]{4}{*}{$\mathrm{X} 3$ = Emosi } & X3.1 & 0,551 & 0,227 & Valid \\
\hline & $\mathrm{X} 3.2$ & 0,613 & 0,227 & Valid \\
\hline & X3.3 & 0,685 & 0,227 & Valid \\
\hline & X3.4 & 0,631 & 0,227 & Valid \\
\hline \multirow[t]{3}{*}{ X4 = Persepsi } & $\mathrm{X} 4.1$ & 0,786 & 0,227 & Valid \\
\hline & $\mathrm{X} 4.2$ & 0,521 & 0,227 & Valid \\
\hline & $\mathrm{X} 4.3$ & 0,785 & 0,227 & Valid \\
\hline \multirow[t]{2}{*}{ X5 = Pembelajaran } & $\mathrm{X} 5.1$ & 0,638 & 0,227 & Valid \\
\hline & $\mathrm{X} 5.2$ & 0,661 & 0,227 & Valid \\
\hline \multirow[t]{2}{*}{ X6 = Kepribadian } & X6.1 & 0,647 & 0,227 & Valid \\
\hline & X6.2 & 0,660 & 0,227 & Valid \\
\hline \multirow{3}{*}{$\begin{array}{ll}\text { Y } \quad= & \text { Sistem } \\
\text { Akuntansi } & \\
\text { Persediaan } & \end{array}$} & Y1.1 & 0,638 & 0,227 & Valid \\
\hline & Y1.2 & 0,600 & 0,227 & Valid \\
\hline & Y1.3 & 0,838 & 0,227 & Valid \\
\hline
\end{tabular}

Berdasarkan Tabel 3.1 dapat diketahui bahwa poin-poin pada setiap pernyataan telah memenuhi syarat validitas atau dinyatakan valid dilihat dari nilai Pearson Correlation atau r- hitung lebih besar dari $r$ tabel yaitu 0.227. 
2. Uji Reliabilitas

Uji Reliabilitas dapat dilakukan bersama-sama terhadap poin-poin pernyataan. Jika nilai Alpha > 0,60 maka pernyataan dikatakan reliabel dengan melihat nilai Cronbach's Alpha.

Tabel 3.2

Uji Reliabilitas

\begin{tabular}{|c|c|c|r|}
\hline Variabel & $\begin{array}{c}\text { Cronbach's } \\
\text { Alpha }\end{array}$ & $\begin{array}{c}\text { Standar } \\
\text { Reliabilita } \\
\text { S }\end{array}$ & Keterangan \\
\hline X1 (Sikap) & 0,716 & 0,60 & Reliabel \\
\hline X2 (Motivasi) & 0,619 & 0,60 & Reliabel \\
\hline X3 (Emosi) & 0,646 & 0,60 & Reliabel \\
\hline X4 (Persepsi) & 0,617 & 0,60 & Reliabel \\
\hline X5(Pembelajaran) & 0,693 & 0,60 & Reliabel \\
\hline X6 (Kepribadian) & 0,652 & 0,60 & Reliabel \\
\hline $\begin{array}{c}\text { Y (Sistem Akuntasi } \\
\text { Persediaan) }\end{array}$ & 0,674 & 0,60 & Reliabel \\
\hline
\end{tabular}

Berdasarkan Tabel 3.2 berdasarkan Cronbach Alpha's >0.60 maka setiap variabel dinyatakan reliabel.

\section{Uji Asumsi Klasik}

1. Uji Normalitas

Data Pengujian normalitas menggunakan Kolmogorov-Sminrnov dengan kriteria Jika signifikan $<0,05$, maka data dikatakan tidak normal dan jika signifikan > 0,05 maka data dikatakan normal.

Tabel 3.3

Uji Normalitas Kolmogorov-Smirnov

\begin{tabular}{|c|c|c|}
\hline $\begin{array}{c}\text { Asymp } \\
\text { Sig }\end{array}$ & $\begin{array}{c}\text { Standar } \\
\text { Normalitas }\end{array}$ & Keterangan \\
\hline 0,200 & 0,05 & Terdistribusi Normal \\
\hline
\end{tabular}

Berdasarkan Tabel 3.3 dapat diketahui bahwa variabel independen dan variabel dependen dalam penelitian ini berdistribusi normal karena memiliki nilai signifikansi $>0.05$ yaitu 0.200 .

2. Uji Multikolinearitas

Untuk menguji gejala Multikolinearitas ini dengan melihat tolerance value atau Variance Inflation Factor (VIF) dimana apabila tolerance value $>0,1$ dan VIF $<$ 10 maka tidak terjadi gejala multikolinearitas antar variabel independen dan apabila tolerance value $<0,1$ dan VIF $>10$ maka terjadi gejala multikolinearitas antar variabel independen. 
Tabel 3.4

Hasil Uji Multikolinearitas

\begin{tabular}{|l|l|r|l|}
\hline Variabel & Tolerance & VIF & \multicolumn{1}{|c|}{ Keterangan } \\
\hline Sikap (X1) & 0,909 & 1,100 & $\begin{array}{l}\text { Tidak Terjadi } \\
\text { Multikolinearitas }\end{array}$ \\
\hline Motivasi (X2) & 0,907 & 1,102 & $\begin{array}{l}\text { Tidak Terjadi } \\
\text { Multikolinearitas }\end{array}$ \\
\hline Emosi (X3) & 0,919 & 1,088 & $\begin{array}{l}\text { Tidak Terjadi } \\
\text { Multikolinearitas }\end{array}$ \\
\hline Persepsi (X4) & 0,843 & 1,186 & $\begin{array}{l}\text { Tidak Terjadi } \\
\text { Multikolinearitas }\end{array}$ \\
\hline $\begin{array}{l}\text { Pembelajaran } \\
\text { (X5) }\end{array}$ & 0,670 & 1,493 & $\begin{array}{l}\text { Tidak Terjadi } \\
\text { Multikolinearitas }\end{array}$ \\
\hline $\begin{array}{l}\text { Kepribadian } \\
\text { (X6) }\end{array}$ & 0,658 & 1,519 & $\begin{array}{l}\text { Tidak Terjadi } \\
\text { Multikolinearitas }\end{array}$ \\
\hline
\end{tabular}

Berdasarkan Tabel 3.4 dapat diketahui bahwa nilai tolerance value dari ke enam variabel memiliki nilai $>0.1$ dan nilai VIF.

3. Uji Heteroskedastisitas

Untuk menguji gejala heteroskedastisidas, dalam penelitian ini menggunakan grafik lot antara nilai prediksi variabel terikat (ZPRED) dengan residualnya (SRESID).

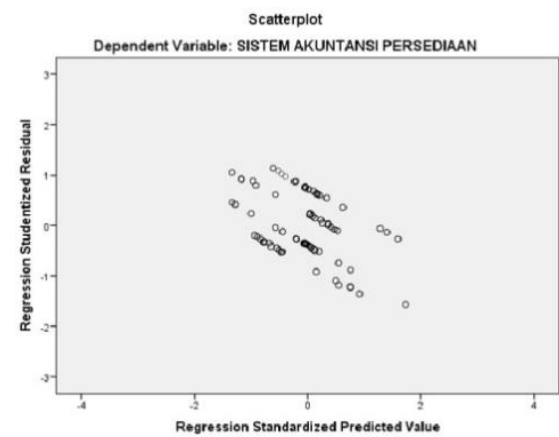

Gambar 3.1

Hasil Uji Hetereoskedastisitas

Berdasarkan Gambar 3.1 terlihat bahwa grafik scatter plot, titik-titik pada gambar tersebut menyebar di atas dan di bawah angka nol pada sumbu $\mathrm{Y}$ dan tidak membentuk pola bergelombang, melebar dan menyempit, maka dapat disimpulkan bahwa tidak terjadi masalah heteroskedastisitas.

\section{Uji Regresi Linier Berganda}

Analisis regresi berganda digunakan untuk mengetahui pengaruh antara antar variabel dependen dengan variabel independen baik secara parsial maupun secara simultan. 
Tabel 3.5

Hasil Analisi Regresi Linear Berganda

\begin{tabular}{|c|c|c|c|c|c|c|}
\hline \multicolumn{7}{|c|}{ Coefficients $^{\mathrm{a}}$} \\
\hline \multirow{2}{*}{\multicolumn{2}{|c|}{ Model }} & \multicolumn{2}{|c|}{$\begin{array}{l}\text { Unstandardized } \\
\text { Coefficients }\end{array}$} & \multirow{2}{*}{$\begin{array}{c}\begin{array}{c}\text { Standardiz } \\
\text { ed } \\
\text { Coefficient } \\
\text { s }\end{array} \\
\text { Beta }\end{array}$} & \multirow[t]{2}{*}{$\mathrm{T}$} & \multirow[t]{2}{*}{ Sig. } \\
\hline & & B & $\begin{array}{l}\text { Std. } \\
\text { Error }\end{array}$ & & & \\
\hline \multirow[t]{7}{*}{1} & (Constant) & 11.594 & 3.132 & & 2.105 & .039 \\
\hline & SIKAP & .131 & .066 & .018 & 3.166 & .003 \\
\hline & MOTIVASI & .009 & .099 & .010 & 2.195 & .001 \\
\hline & EMOSI & .314 & .090 & .124 & 4.157 & .000 \\
\hline & PERSEPSI & .515 & .112 & .115 & 3.027 & .002 \\
\hline & $\begin{array}{l}\text { PEMBELAJA } \\
\text { RAN }\end{array}$ & .340 & .208 & .024 & 3.193 & .003 \\
\hline & $\begin{array}{l}\text { KEPRIBADI } \\
\text { AN }\end{array}$ & .816 & .203 & .510 & 4.027 & .000 \\
\hline
\end{tabular}

Berdasarkan ouput diatas dapat diperoleh hasil persamaan analisis regresi linear berganda yaitu :

$$
\begin{aligned}
Y= & a+b 1 X 1+b 2 X 2+b 3 X 3+b 4 X 4+b 5 X 5+b 6 X 6 \\
Y= & 11,594+0,131 X 1+0,009 X 2+0,314 X 3+0,515 X 4+0,340 X 5+ \\
& 0,816 X 6
\end{aligned}
$$

Dengan konstanta sebesar 11,594, koefisien Sikap sebesar 0,131, koefisien Motivasi sebesar 0,009, koefisien Emosi sebesar 0,314, koefisien Persepsi sebesar 0,515, koefisien Pembelajaran sebesar 0,340, koefisien Kepribadian sebesar 0,816 dengan standar t-eror 0,05 . Persamaan regresi di atas dapat dijelaskan seperti dibawah ini :

1. Konstanta (a) memiliki nilai koefisien positif artinya Sitem Akuntansi Persediaan pada CV. Senyum Media sudah dilaksanakan dengan baik meskipun belum dilakukan secara maksimal.

2. Variabel Sikap (X1) terhadap Sitem Akuntansi Persediaan (Y) koefisien regresi nya sebesar 0,131 artinya hubungan antara Sikap dengan Sistem Akuntansi Persediaan searah dan positif, jika Sikap berjalan secara baik maka Sistem Akuntansi Persediaan juga berjalan dengan baik.

3. Motivasi (X2) terhadap Sistem Akuntansi Persediaan (Y) koefisien regresi nya sebesar 0,009 artinya hubungan antara Motivasi dengan Sistem Akuntansi Persediaan searah dan positif, jika Motivasi semangat kerja dimiliki oleh seluruh karyawan maka Sitem Akuntansi Persediaan juga berjalan dengan baik.

4. Variabel Emosi (X3) terhadap Sistem Akuntansi Persediaan (Y) koefisien regresi nya sebesar 0,314 artinya hubungan antara Emosi dengan Sistem Akuntansi Persediaan searah dan positif, jika Emosi pola pikir karyawan baik maka Sitem Akuntansi Persediaan juga berjalan dengan baik.

5. Variabel Persepsi (X4) terhadap Sistem Akuntansi Persediaan (Y) koefisien regresi nya sebesar 0,515 artinya hubungan antara Persepsi dengan Sistem Akuntansi 
Persediaan searah dan positif, jika Persepsi karyawan terhadap perusahaan baik maka Sitem Akuntansi Persediaan juga berjalan dengan baik.

6. Variabel Pembelajaran (X5) terhadap Sistem Akuntansi Persediaan (Y) koefisien regresi nya sebesar 0,340 artinya hubungan antara Pembelajaran dengan Sistem Akuntansi Persediaan searah dan positif, jika Pembelajaran setiap karyawan dalam melakukan setiap pekerjaan dengan benar maka Sitem Akuntansi Persediaan juga berjalan dengan baik.

7. Variabel Kepribadian (X6) terhadap Sistem Akuntansi Persediaan (Y) koefisien regresi nya sebesar 0,816 artinya hubungan antara Kepribadian dengan Sistem Akuntansi Persediaan searah dan positif, jika Kepribadian yang dimiliki setiap karyawan itu baik maka Sistem Akuntansi Persediaan juga berjalan dengan baik.

\section{Koefisien Determinasi}

Berdasarkan Tabel 3.5 diperoleh nilai Adjusted $R$ Square sebesar 0,328 dimana variabel independen mampu menjelaskan sebesar $32,8 \%$ terhadap variasi/permodelan pada variabel dependen. Hasil koefisien determinasi terhitung rendah akan tetapi dapat digunakan sebagai bahan penelitian, karena koefisien determinasi hanya salah satu bukan satu-satunya kriteria memilih model yang baik. Artinya ada variabel-variabel lain yang lebih memengaruhi dari variabel yang peneliti ambil. Seperti variabel pelatihan, variabel disiplin, dan variabel partisipasi.

\section{Uji F (Simultan)}

Berdasarkan Tabel 3.5 dapat dilihat $\mathrm{F}$ hitung sebesar 11,459 berarti nilai $\mathrm{F}$ hitung lebih besar dari $\mathrm{F}$ tabel yaitu 4,32. Berdasarkan kedua kriteria tersebut dapat disimpulkan bahwa variabel Sikap, Motivasi, Emosi, Persepsi, Pembeljaran, dan Kepribadian secara simultan atau keseluruhan berpengaruh terhadap Sistem Akuntansi Persediaan.

\section{Uji t (Parsial)}

Berdasarkan Tabel di atas dapat dilihat masing-masing t-hitung pada variabel Sikap sebesar 3,166, Motivasi sebesar 2,195, Emosi sebesar 4,157, Persepsi sebesar 3,027, Pembelajaran sebesar 3,193, Kepribadian sebesar 4,027. Berdasarkan hal tersebut bisa diketahui bahwa nilai signifikan apabila sig $<0,05$ maka berpengaruh dan apabila sig > 0,05 maka tidak berpengaruh, berdasarkan tabel diatas nilai signifikan X1, X2, X3, X4, X5, X6 lebih kecil dari 0,05 maka secara parsial variabel berpengaruh terhadap Y. 


\section{PEMBAHASAN}

\section{Pengaruh Sikap, Motivasi, Emosi, Persepsi, Pembelajaran, dan Kepribadian Terhadap Sistem Akuntansi Persediaan}

Berdasarkan hasil pengujian hipotesis dapat diketahui nilai signifikansi Sikap, Motivasi, Emosi, Persepsi, Pembelajaran, dan Kepribadian terhadap Sistem Akuntansi Persediaan sebesar 0,000 $<0,05$ dengan nilai t-hitung sebesar 11,459 sehingga dapat disimpulkan bahwa Sikap, Motivasi, Emosi, Persepsi, Pembelajaran, dan Kepribadian secara simultan mempunyai hubungan positif dan berpengaruh terhadap Sistem Akuntansi Persediaan.

Hal ini sejalan dengan penelitian yang dilakukan oleh Evalina Marantika Akay, Agus T. Poputra, Meily Y. B. Kalalo (2016) yang menyatakan bahwa Sikap, Motivasi, Persepsi, dan Emosi berpengaruh signifikan terhadap sistem akuntansi persediaan. Dan sejalan juga dengan penelitian Ketut Sudarma, Eva M. Sakdiyah (2007) yang menyatakan bahwa hasil penelitiannya menunjukkan bahwa Pembelajaran berpengaruh positif terhadap prestasi belajar akuntansi.

\section{Pengaruh Sikap Terhadap Sistem Akuntansi Persediaan}

Berdasarkan hasil penelitian Sikap berpengaruh signifikan terhadap Sistem Akuntansi Persediaan. Dengan demikian hipotesis yang menyatakan Sikap berpengaruh terhadap Sistem Akuntansi Persediaan diterima. Hal ini menunjukkan bahwa Sikap karyawan pada CV. Senyum Media sangat baik.

Seorang karyawan mungkin membentuk sikap positif atau negatif terhadap usulan kebijakan perusahaan, bergantung pada apakah kebijakan tersebut dilihat sesuatu yang baik oleh karyawan itu. Hal ini sependapat dengan temuan di lapang yang megatakan bahwa seluruh koresponden memiliki Sikap yang mendukung terhadap Sistem Akuntansi Persediaan. Sesuai dengan indikator-indikator sikap dimana karyawan memiliki sikap yang jujur dalam melakukan setiap pekerjaannya, dan juga selalu bersikap disiplin ketika melakukan suatu pekerjaan.

Hal ini sejalan dengan penelitian sikap yang dilakukan oleh Rombe, Poputra dan Kalolo (2015) yang menyatakan bahwa hasil penelitiannya menunjukkan Sikap berpengaruh signifikan terhadap sistem kas dalam pelaporan arus kas.

\section{Pengaruh Motivasi Terhadap Sistem Akuntansi Persediaan}

Berdasarkan hasil penelitian Motivasi berpengaruh signifikan terhadap Sistem Akuntansi Persediaan. Dengan demikian hipotesis yang menyatakan Motivasi berpengaruh terhadap Sistem Akuntansi Persediaan diterima. Hal ini menunjukkan bahwa Motivasi karyawan pada CV. Senyum Media sangat baik.

Motivasi merupakan suatu konsep penting untuk perilaku akuntan, karena efektivitasnya organisasional bergantung pada orang yang membentuk sebagaimana karyawan mengharapkan untuk dibentuk. Manajer dan akuntan keperilakuan harus memotivasi orang kearah kinerja yang diharapkan dalam rangka memenuhi tujuan organisasi. Hal ini sependapat dengan temuan di lapang yang megatakan bahwa seluruh koresponden memiliki Motivasi yang mendukung terhadap Sistem Akuntansi Persediaan. Sesuai dengan indikator-indikator motivasi dimana karyawan memiliki keahlian yang baik dalam melakukan setiap pekerjaannya.

Hal ini sejalan dengan penelitian motivasi yang dilakukan oleh Wulan Mogantha, Grace B Nangoi, Natalia Gerungai (2017) yang menyatakan bahwa hasil penelitiannya 
menunjukkan Motivasi berpengaruh signifikan terhadap terhadap sistem akuntansi yang ada di PT. Sinar Galesong Prima.

Hasil penelitian ini juga bertolak belakang dengan penelitian Budianto Ngo, Rofingatun Siti , Mariolin A. Sanggenafa (2019), menyatakan bahwa variabel motivasi tidak berpengaruh signifikan terhadap sistem akuntansi. Hal ini menunjukkan bahwa variabel motivasi pada penelitian ini tidak berpengaruh terhadap kinerja karyawan.

\section{Pengaruh Emosi Terhadap Sistem Akuntansi Persediaan}

Berdasarkan hasil penelitian Emosi berpengaruh signifikan terhadap Sistem Akuntansi Persediaan. Dengan demikian hipotesis yang menyatakan Emosi berpengaruh terhadap Sistem Akuntansi Persediaan diterima. Hal ini menunjukkan bahwa karyawan pada CV. Senyum Media memiliki emosi yang positif, sehingga dapat melakukan pekerjaan dengan baik.

Emosi merupakan perasaan intens yang diarahkan pada seseorang atau sesuatu. Emosi berbeda dari suasana hati ( $\operatorname{moods})$, yaitu merasakan kecenderungan yang kurang intens dibandingkan emosi dan kekurangan satu rangsangan kontekstual. Emosi merupakan reaksi terhadap satu objek, dan akhirnya tidak bertahan pada ciri kepribadian setiap karyawan. Hal ini sependapat dengan temuan di lapang yang megatakan bahwa seluruh koresponden memiliki Emosi positif , seluruh karyawan yang memiliki rasa tidak pernah menyerah ketika melakukan suatu pekerjaan dan merasa sedih apabila pekerjaan yang ia lakukan tidak dapat cepat terselesaikan maka dengan demikian mereka selalu dapat menyelesaikan pekerjaannya dengan tepat waktu.

Hal ini sejalan dengan penelitian emosi yang dilakukan oleh Tingkas Kurniyanti (2019) yang menyatakan bahwa hasil penelitiannya menunjukkan Emosi secara parsial berpengaruh signifikan terhadap persediaan barang.

Hasil penelitian ini juga bertolak belakang dengan penelitian Wulan Mogantha, Grace B Nangoi, Natalia Gerungai (2017), menyatakan bahwa variabel emosi kurang berpengaruh signifikan terhadap sistem akuntansi. Hal ini menunjukkan bahwa variabel emosi pada penelitian ini kurang berpengaruh terhadap kinerja karyawan.

\section{Pengaruh Persepsi Terhadap Sistem Akuntansi Persediaan}

Berdasarkan hasil penelitian Persepsi berpengaruh signifikan terhadap Sistem Akuntansi Persediaan. Dengan demikian hipotesis yang menyatakan Persepsi berpengaruh terhadap Sistem Akuntansi Persediaan diterima. Hal ini menunjukkan bahwa karyawan pada CV. Senyum Media memiliki persepsi yang sangat baik, sehingga dapat melakukan pekerjaan dengan baik.

Pada kenyataanya, setiap orang memiliki persepsinya sendiri atas suatu kejadian. Uraian kenyataan seseorang mungkin jauh berbeda dengan uraian orang lain. Definisi persepsi yang formal adalah proses di mana seseorang memilih, berusaha, dan menginterprestasikan rangsangan ke dalam suatu gambaran yang terpadu dan penuh arti. Hal ini sependapat dengan temuan di lapang yang megatakan bahwa seluruh koresponden memiliki Persepsi yang sangat baik, seluruh karyawan selalu memberikan tanggapan antar karyawan lainnya atas pekerjaan yang telah dilakukan, dan juga karyawan selalu melakukan penilaian terhadap diri sendiri atas pekerjaan yang telah dilakukan apa sudah baik atau tidak.

Hal ini sejalan dengan penelitian persepsi yang dilakukan oleh Apriwandi, Yuma 
Ardilla (2012) yang menyatakan bahwa hasil penelitiannya menunjukkan memiliki pengaruh positif terhadap komitmen pada tujuan. Semakin tinggi persepsi mengenai keadilan distributif, maka komitmen pada tujuan akan semakin besar.

\section{Pengaruh Pembelajaran Terhadap Sistem Akuntansi Persediaan}

Berdasarkan hasil penelitian Pembelajaran berpengaruh signifikan terhadap Sistem Akuntansi Persediaan. Dengan demikian hipotesis yang menyatakan Pembelajran berpengaruh terhadap Sistem Akuntansi Persediaan diterima. Hal ini menunjukkan bahwa karyawan pada CV. Senyum Media dalam melakukan setiap pekerjaan selalu didasari atas pembelajaran yang telah mereka peroleh.

Pembelajaran terjadi sebagai hasil dari motivasi, pengalaman, dan pengulangan dalam merespons situasi. Kombinasi dari motivasi, pengalaman, dan pengulangan dalam merespons situasi ini terjadi dalam tiga bentuk : pengaruh keadaan klasik, pengaruh keadaan operant, dan pembelajaran sosial. Hal ini sependapat dengan temuan di lapang yang megatakan bahwa seluruh koresponden memiliki Pembelajaran yang sangat baik, dalam melakukan suatu pekerjaan karyawan selalu menggunakan pengalaman dan meminimalisir kesalahan sehingga sistem akuntansi yang dikerjakan sangat baik.

Hal ini sejalan dengan penelitian persepsi yang dilakukan oleh Ketut Sudarma, Eva M. Sakdiyah (2007) yang menyatakan bahwa hasil penelitiannya menunjukkan bahwa Pembelajaran berpengaruh positif terhadap prestasi belajar akuntansi.

Hasil penelitian ini juga bertolak belakang dengan penelitian Budianto Ngo, Rofingatun Siti , Mariolin A. Sanggenafa (2019), menyatakan bahwa variabel persepsi tidak berpengaruh signifikan terhadap sistem akuntansi. Hal ini menunjukkan bahwa variabel persepsi pada penelitian ini tidak berpengaruh terhadap kinerja karyawan.

\section{Pengaruh Pembelajaran Terhadap Sistem Akuntansi Persediaan}

Berdasarkan hasil penelitian Kepribadian berpengaruh signifikan terhadap Sistem Akuntansi Persediaan. Dengan demikian hipotesis yang menyatakan Kepribadian berpengaruh terhadap Sistem Akuntansi Persediaan diterima. Hal ini menunjukkan bahwa karyawan pada CV. Senyum Media dalam melakukan setiap pekerjaan selalu didasari atas kepribadian yang baik.

Kepribadian mengacu pada bagian karakteristik psikologi dalam diri seseorang yang menentukan dan mencerminkan bagaimana orang tersebut merespons lingkungannya.Pengujian perilaku ditentukan oleh banyaknya efektivitas dalam tekanan pekerjaan, siapa yang akan menanggapi kritikan dengan baik, siapa yang pertama harus dipuji dahulu sebelum berbicara mengenai perilaku tidak diinginkan, siapa yang menjadi seorang pemimpin potensial, siapa yang bekerja lebih baik dalam suatu lingkungan pekerjaan partisipatif, siapa yang kelihatannya dapat dipercaya, dan seterusnya. Hal ini sependapat dengan temuan di lapang yang megatakan bahwa seluruh koresponden memiliki Kepribadian yang sangat baik, karyawan melakukan pekerjannya dengan sangat percaya diri, dengan demikian sistem akuntansi persediaan menjadi lebih baik.

Hal ini sejalan dengan penelitian persepsi yang dilakukan oleh Temen Koesmono (2004) yang menyatakan bahwa hasil penelitian menunjukkan bahwa Kepribadian berpengaruh terhadap perilaku karyawan secara positif, Kepribadian juga berpengaruh terhadap komitmen organisasi secara positif. 


\section{KESIMPULAN}

Penelitian ini bertujuan untuk menganalisis pengaruh Sikap, Motivasi, Emosi, Persepsi, Pembelajaran, dan Kepribadian terhadap Sistem Akuntansi Persediaan. Dari berbagai pembahasan yang telah dilakukan sebelumnya, maka dapat ditarik kesimpulan sebagai berikut :

1. Sikap, Motivasi, Emosi, Persepsi, Pembelajaran, dan Kepribadian secara simultan berpengaruh signifikan terhadap Sistem Akuntansi Persediaan.

2. Sikap, Motivasi, Emosi, Persepsi, Pembelajaran, dan Kepribadian secara parsial berpengaruh signifikan terhadap Sistem Akuntansi Persediaan.

\section{DAFTAR PUSTAKA}

Firdaus, Muhammad. (2019). Ekonometrika Suatu Pendekatan Aplikatif. Jakarta: PT. Bumi Aksara.

Ghozali, I. (2016). Aplikasi Analisis Multivariate Dengan Program IBM SPSS 2. Semarang: Badan Penerbit Universitas Diponegoro.

Prima Surabaya. AGORA Vol. 5, No. 1, (2017), 8.

Lubis, Arfan Ikhsan. 2010. Akuntansi Keperilakuan. Salemba Empat, Jakarta Priyatno, Duwi. 2013. Analisis Korelasi, Regresi, dan Multivariate dengan SPSS. Gava Media, Yogyakarta

Purwanti dan Hudiwinarsih. 2012. Persepsi manajer atas informasi akuntansi keuangan dan pengaruhnya pada keberhasilan mengelola perusahaan kecil dan menengah di Surabaya.

Reeve, James., Warren, Jonathan, Wahyuni, Supriyanto, Jusuf dan Djakman. 2013.

Pengantar Akuntansi. Salemba Empat, Jakarta

Suartana, I Wayan. 2010. Akuntansi Keperilakuan Teori dan Implementasi. ANDI, Jakarta.

Sugiyono. 2010. Metode Penelitian Bisnis (Pendekatan Kuantitatif, Kualitatif dan R\&D. Alfabeta, Bandung

Sujarweni, Wiratna. 2015. Sistem Akuntansi. Pustaka Baru Press, Yogyakarta. Sukardi, Metodologi Penelitian Pendidikan Kompetensi dan Praktiknya (Jakarta : PT Bumi Aksara, 20130, h.33

Suryantara, I Gusti Ngurah. 2014. Merancang Aplikasi Akuntansi dengan VB.Net.Elex Media Komputindo, Jakarta V. Wiratna Sujarweni, Metodologi Penelitian (Y ogyakarta : Pustaka Baru Press, 2014),h.57

Wibowo. 2014. Perilaku dalam Organisasi. Rajagrafindo Persada, Jakarta. 
Akay, Poputra, Kalalo, 2016. Aspek Keperilakuan Terhadap Penerapan Sistem Akuntansi Persediaan Pada PT. Surya Wenang Indah Manado. Jurnal EMBA ISSN 23031174.

Anmar Rombe, A. T. (2016). Analisis Sistem Kas Berbasis Akuntansi Keperilakuan Dalam Pelaporan Arus Kas Pada Pt. Bank Sulutgo. Volume 16 No. 01 Tahun 2016, 10.

Budianto Ngo, D. S. (2019). Analisis Pengaruh Aspek Keperilakuan Terhadap Penggunaan Sistem Akuntansi(Studi Pada Pt. Bank X Tbk Di Wilayah Kota Dan Kabupaten Jayapura). Jurnal Akuntansi \& Keuangan Daerah Volume 14, Nomor 2, November 2019: 18-23, 5.

Indriani dan Loulyta. 2008. Pengaruh variabel perilaku karyawan akuntansi terhadap kinerja perusahaan (Studi empiris pada BUMN dan BUMD di Banda Aceh. Jurnal Telaah dan Riset Akuntansi.

Lidia Lusri, H. S. (2017). Pengaruh Motivasi Kerja Terhadap Kinerja Karyawan Melalui Kepuasan Kerja Sebagai Variabel Mediasi Pada Karyawan PT. Borwita Citra

Wulan Mogontha, Grace B Nangoi2, Natalia Gerungai. 2017. Jurnal Riset Akuntansi Going Concern 12(2), 2017, 1055-1062.

Yelfindi Purba, H. K. (2019). Analisis Perlakuan Akuntansi Terhadap Persediaan Barang Usang Pada Pt. Sinar Niaga Sejahtera (Distributor Garuda Food) Manado. Going Concern : Jurnal Riset Akuntansi 14(3), 2019, 278-284, 6.

Yulistia, N. Y. (2017). Analisis Faktor Keperilakuan Organisasi Terhadap Kegunaan Sistem Akuntansi Keuangan Di Badan Keuangan Daerah Pemerintah Provinsi Sumatera Barat. Jurnal Benefita 2(3) Oktober 2017 (179-193), 14. 